\title{
Korelasi Usia dan Derajat Osteoartritis Sendi Lutut Berdasarkan Sistem Klasifikasi Kellgren-Lawrence di RSUP Dr. Hasan Sadikin Bandung Tahun 2019-2020
}

\author{
Correlation Between Age and Primary Knee Osteoarthritis Grade According to \\ Kellgren-Lawrence Classification System in RSUP Dr. Hasan Sadikin Bandung in \\ 2019-2020
}

\author{
Jonathan J Sibarani $^{1 *}$, Atta Kuntara ${ }^{2}$, Renaldi P H N Rasyid ${ }^{3}$ \\ ${ }^{1}$ Fakultas Kedokteran Universitas Padjajaran, Bandung \\ ${ }^{2}$ Departemen Radiologi Fakultas Kedokteran Universitas Padjadjaran/Rumah Sakit Umum \\ Hasan Sadikin Bandung \\ ${ }^{3}$ Departemen Orthopaedi dan Traumatologi Fakultas Kedokteran Universitas \\ Padjadjaran/Rumah Sakit Umum Hasan Sadikin Bandung \\ "Penulis korespondensi \\ Email: jonathan17002@mail.unpad.ac.id
}

Received: December 23, 2020

Accepted: February 22, 2021

\begin{abstract}
Abstrak
Osteoartritis adalah penyakit sendi yang paling sering mengakibatkan disabilitas pada usia lanjut. Sendi lutut merupakan sendi dengan predileksi tersering untuk menderita osteoartritis. Penelitian ini bertujuan untuk meneliti korelasi antara usia dan derajat osteoartritis sendi lutut primer berdasarkan sistem klasifikasi Kellgren-Lawrence di Departemen Radiologi RSUP Dr. Hasan Sadikin Bandung pada tahun 2019-2020. Penelitian ini dilakukan dengan disain penelitian potong lintang, metode analitis korelasi Spearman. Penelitian ini menggunakan foto rontgen pasien osteoartritis sendi lutut primer di Departemen Radiologi RSHS pada periode 1 Januari 2019 - 29 Februari 2020 (n=67). Derajat osteoartritis sendi lutut dinilai oleh konsultan radiologi RSHS. Hasil penelitian menunjukkan osteoartritis sendi lutut primer paling sering ditemukan pada kelompok usia 55-59 tahun dengan jumlah pasien sebanyak 14 orang $(20,9 \%)$ dan paling jarang ditemukan pada kelompok usia 40-44 tahun dengan jumlah pasien sebanyak 2 orang (3\%). Osteoartritis sendi lutut derajat berat paling sering ditemukan pada kelompok usia 55-59 tahun dan 60-64 tahun dengan jumlah pasien osteoartritis derajat berat pada masing-masing kelompok usia tersebut sebanyak 3 pasien (33,3\%). Hasil analisis menunjukkan koefisien korelasi sebesar $0,15(\mathrm{p}=0,224)$ sehingga tidak terdapat korelasi antara usia dan derajat osteoartritis sendi lutut primer. Simpulan penelitian, tidak terdapat korelasi antara usia dan derajat osteoartritis sendi lutut primer.
\end{abstract}

Kata kunci: Kellgren-Lawrence; korelasi, osteoartritis sendi lutut primer; usia 


\title{
Research Article
}

\begin{abstract}
Osteoarthritis is a joint disease that commonly causes disability in the elderly. This research aimed to find the correlation between age and primary knee osteoarthritis grade according to the Kellgren-Lawrence classification system in patients in the Department of Radiology of RSUP Dr. Hasan Sadikin Bandung. This research was a cross-sectional study. This research used Spearman's correlation method. This research used X-ray results from the Department of Radiology of RSHS from 1 January 2019-29 February 2020 (n=67). The grade of knee osteoarthritis was diagnosed by a radiology consultant of RSHS. This study found that primary knee osteoarthritis was most commonly found in the 55-59 years age group, as many as 14 patients (20,9\%) and least commonly found in the 40-44 years age group, as many as 2 patients (3\%). Severe osteoarthritis was most commonly found in the 55-59 years age group and 60-64 years age group with the number of severe osteoarthritis patients within each age group were 3 patients $(33,3 \%)$. The correlation coefficient was $-0,15(p=0,224)$ hence there was no correlation between age and grade of primary knee osteoarthritis. Conclusion, there was no correlation between age and grade of primary knee osteoarthritis in the Radiology Department of RSHS in 2019-2020.
\end{abstract}

Keywords: Age; correlation; Kellgren-Lawrence; primary knee osteoarthritis

\section{Pendahuluan}

Osteoartritis adalah penyakit pada sendi yang paling sering mengakibatkan disabilitas pada usia lanjut. Osteoartritis merupakan suatu penyakit degeneratif sendi. ${ }^{1,2}$ Salah satu sendi yang paling sering mengalami osteoartritis adalah sendi lutut. ${ }^{3}$ Osteoartritis berdampak buruk terhadap aspek sosial ekonomi. Osteoartritis menurunkan produk domestik bruto negara maju sebesar 1\%-2,5\%. ${ }^{4}$ Prevalensi osteoartritis sendi lutut di Indonesia sebesar 15,5\% pada pria dan $12,7 \%$ pada wanita yang berusia di antara 40-60 tahun. Penelitian di klinik reumatologi RSUP Dr. Hasan Sadikin Bandung pada tahun 2007 dan 2010 mendapatkan bahwa osteoartritis merupakan 74,48\% dari seluruh kasus nyeri sendi pada tahun 2007, dan 87\% dari kasus osteoartritis merupakan osteoartritis sendi lutut. ${ }^{5,6}$

Beberapa faktor risiko dapat berpengaruh terhadap onset dan progresi dari osteoartritis. Faktor risiko tersebut berupa faktor genetik, usia, gender, ras, diet, obesitas, paparan terhadap spesies oksigen reaktif, konsentrasi glukosa darah yang tinggi, adipokin, dan aktivitas fisik. Di antara seluruh faktor risiko yang sudah disebutkan di atas, faktor risiko yang paling berpengaruh terhadap osteoartritis adalah usia. ${ }^{1,7}$ Seiring bertambahnya usia, kartilago juga akan mengalami penuaan. Kartilago yang menua ini akan mengalami disfungsi mitokondria sehingga spesies oksigen reaktif dalam kondrosit meningkat. Spesies oksigen reaktif ini mengakibatkan hiperoksidasi antioksidan peroksiredoksin, akibatnya peroksiredoksin tidak dapat meregulasi 


\section{Research Article}

signaling pathway pada kartilago sehingga terjadi inhibisi PI3K-AKT pathway yang menurunkan sintesis matriks kartilago dan aktivasi MAPK pathway yang meningkatkan sintesis enzim pendegradasi matriks. Penurunan sintesis matriks kartilago dan peningkatan enzim pendegradasi matriks menyebabkan destruksi kartilago yang mengakibatkan osteoartritis. ${ }^{8}$

Osteoartritis sendi lutut diklasifikasikan menjadi 2 tipe berdasarkan penyebabnya; yaitu osteoartritis primer dan osteoartritis sekunder. Osteoartritis yang diakibatkan oleh fenomena penuaan yang idiopatik adalah osteoartritis primer. Osteoartritis sekuner terjadi pada individu yang berusia lebih muda akibat adanya kondisi yang merupakan faktor predisposisi dari osteoartritis seperti cedera sendi, deformitas sendi akibat kecelakaan, dan karena penyakit sistemik seperti diabetes, nekrosis avaskular, atau obesitas. ${ }^{2}$

Osteoartritis primer lebih sering terjadi daripada osteoartritis sekunder. Diagnosis osteoartritis primer ditegakkan jika pada pasien tidak ditemukan riwayat trauma atau penyakit sistemik yang merupakan faktor predisposisi dari osteoartritis. ${ }^{9}$ Osteoartritis didiagnosis melalui anamnesis dengan menanyakan pola rasa sakit pada sendi, pemeriksaan fisik dengan memeriksa rasa sakit dari range of motion pada sendi, dan dari pemeriksaan penunjang berupa foto $x$-ray yang diindikasikan pada osteoartritis sendi lutut jika gejala yang muncul tidak tipikal untuk osteoartritis. ${ }^{1,10}$

Derajat osteoartritis ditentukan berdasarkan kelainan radiologis pada sendi pasien. Terdapat beberapa skala yang dapat digunakan untuk mengklasifikasikan derajat osteoartritis. ${ }^{11}$ Sistem klasifikasi yang paling sering digunakan untuk menentukan derajat osteoartritis sendi lutut adalah sistem klasifikasi Kellgren-Lawrence. Sistem klasifikasi ini menggolongkan osteoartritis sendi lutut menjadi derajat $0-4$, dengan derajat 0 menandakan tidak terdapat osteoartritis dan derajat 4 menandakan terdapat osteoartritis derajat berat. Berdasarkan pedoman dari British Orthopaedic Association, osteoartritis sendi lutut dengan derajat Kellgren-Lawrence >3 merupakan indikasi untuk dilakukan operasi penggantian sendi lutut total. ${ }^{12,13}$

Saat ini, penelitian mengenai korelasi antara usia dan derajat osteoartritis sendi lutut primer berdasarkan sistem klasifikasi Kellgren-Lawrence di RSUP Dr. Hasan Sadikin Bandung masih belum banyak dilakukan. Korelasi antara usia dan derajat osteoartritis sendi lutut primer pada pasien berusia di atas 40 tahun di Departemen Radiologi RSUP Dr. Hasan Sadikin Bandung pada tahun 2019-2020 perlu untuk diteliti, karena dengan mengetahui usia dan jenis kelamin pasien osteoartritis sendi lutut primer dan sebaran derajat osteoartritis pada setiap kelompok usia maka dapat dilakukan screening yang berfokus pada kelompok usia dan jenis 


\section{Research Article}

kelamin yang paling sering menderita osteoartritis sendi lutut primer dan pada kelompok usia yang menderita osteoartritis derajat berat dengan persentase terbesar.

Tujuan penelitian ini adalah untuk mengetahui korelasi antara derajat osteoartritis sendi lutut primer dan usia, meneliti usia dan jenis kelamin pasien osteoartritis sendi lutut primer, dan derajat osteoartritis sendi lutut primer yang diderita oleh setiap kelompok usia.

\section{Metode}

Penelitian ini berlokasi di Departemen Radiologi RSUP Dr. Hasan Sadikin Bandung pada periode 1 Januari 2019 - 29 Februari 2020. Jumlah sampel pada penelitian ini dihitung menggunakan rumus besar sampel penelitian korelatif dengan $\alpha=0,05, \beta=0,1, Z \alpha=1,96, Z_{\beta}=1,28$, dan $r=0,4$ dan didapatkan besar sampel minimal sebesar 62 sampel.

Penelitian ini menggunakan sampel berupa foto rontgen pasien osteoartritis sendi lutut primer yang terdapat di Departemen Radiologi RSUP Dr. Hasan Sadikin Bandung dari periode 1 Januari 2019 - 29 Februari 2020 (n=67). Derajat osteoartritis sendi lutut pada foto rontgen dinilai oleh konsultan radiologi RSUP Dr. Hasan Sadikin Bandung menggunakan sistem klasifikasi yang dibuat oleh Kellgren dan Lawrence.

Sistem klasifikasi Kellgren-Lawrence dipilih karena sistem klasifikasi KellgrenLawrence merupakan sistem klasifikasi dengan inter-observer reliability terbesar untuk oseoartritis sendi lutut. Sistem klasifikasi Kellgren-Lawrence membagi osteoartritis menjadi lima derajat. Derajat 0 berarti tidak ditemukan perubahan radiologis, derajat 1 berarti osteoartritis derajat meragukan, derajat 2 berarti osteoartritis derajat ringan, derajat 3 berarti osteoartritis derajat sedang, dan derajat 4 berarti osteoartritis derajat berat. ${ }^{12,14}$

Osteoartritis derajat 1 ditandai dengan kemungkinan ditemukan osteofit dan penemuan penyempitan celah sendi diragukan, osteoartritis derajat 2 ditandai dengan ditemukan osteofit yang definit dan mungkin terdapat penyempitan celah sendi, osteoartritis derajat 3 ditandai dengan ditemukan osteofit berukuran sedang, ditemukan penyempitan celah sendi yang definit, ditemukan sklerosis, dan mungkin terdapat deformitas pada ujung tulang, dan osteoartitis derajat 4 ditandai dengan ditemukan osteofit besar, ditemukan penyempitan celah sendi yang berat, dan ditemukan deformitas ujung tulang yang definit. ${ }^{12}$

Kriteria inklusi pada penelitian ini adalah pasien berusia di atas 40 tahun yang didiagnosis sebagai osteoartritis sendi lutut primer. Alasan pemilihan pasien dengan usia di atas 40 tahun karena pasien di bawah 40 tahun jarang menderita osteoartritis, apabila menderita osteoartritis, 


\section{Research Article}

lebih sering merupakan osteoartritis sekunder. Kriteria eksklusi pada penelitian ini adalah data rekam medis pasien yang hilang, data rekam medis pasien yang tidak dapat diakses, dan data rekam medis yang tidak lengkap. Data yang telah dikumpulkan akan diolah menggunakan perangkat lunak statistika Microsoft ${ }^{2}$ Excel 2019 dan IBM® SPSS® versi 25 dan ditampilkan dalam bentuk tabel dan grafik.

Disain penelitian ini adalah penelitian potong lintang (cross-sectional), karena penelitian ini menganalisis korelasi antara usia dan derajat osteoartirtis sendi lutut primer, dilakukan dengan metode analitis korelatif Spearman dengan derajat kepercayaan 95\%. Uji hipotesis dinilai berdasarkan nilai $\mathrm{p}$. Jika nilai $\mathrm{p}<0,05$ maka hasil dari analisis data dianggap signifikan dan terdapat korelasi di antara kedua variabel. Jika nilai $\mathrm{p}>0,05$ maka hasil dari analisis data dianggap tidak signifikan dan tidak terdapat korelasi di antara kedua variabel.

Penelitian ini telah mendapat izin dari Komite Etik Penelitian Universitas Padjajaran dengan nomor surat 797/UN6.KEP/EC/2020 tanggal 4 September 2020 dan izin dari Diklit RSUP Dr. Hasan Sadikin Bandung dengan nomor surat LB.02.01/X.2.2.1/20540/2020 tanggal 1 Oktober 2020.

\section{Hasil}

Gambaran usia dan jenis kelamin pada pasien osteoartritis sendi lutut primer di Departemen Radiologi RSUP Dr. Hasan Sadikin Bandung disampaikan pada Tabel 1. Berdasarkan usia, osteoartritis sendi lutut primer paling sering ditemukan pada pasien kelompok usia 55-59 tahun (20,9\%). Usia yang paling jarang mengalami osteoartirtis sendi lutut primer adalah kelompok usia 40-44 tahun (3\%). Osteoartritis sendi lutut primer lebih sering ditemukan pada jenis kelamin perempuan $(71,6 \%)$ daripada laki-laki $(28,4 \%)$. Jumlah pasien osteoartritis sendi lutut primer pada setiap kelompok usia diperlihatkan pada gambar 1. 


\section{Research Article}

Tabel 1 Usia dan Jenis Kelamin Pasien Osteoartritis Sendi Lutut Primer

\begin{tabular}{|c|c|c|c|}
\hline \multirow[t]{2}{*}{ No. } & \multirow[t]{2}{*}{ Usia dan Jenis Kelamin } & \multicolumn{2}{|c|}{ Subjek $(n=67)$} \\
\hline & & $\mathrm{n}$ & $\%$ \\
\hline \multirow[t]{9}{*}{1.} & Usia & & \\
\hline & 40-44 tahun & 2 & $3 \%$ \\
\hline & 45-49 tahun & 5 & $7,5 \%$ \\
\hline & 50-54 tahun & 11 & $16,4 \%$ \\
\hline & 55-59 tahun & 14 & $20,9 \%$ \\
\hline & 60-64 tahun & 9 & $13,4 \%$ \\
\hline & 65-69 tahun & 11 & $16,4 \%$ \\
\hline & 70-74 tahun & 8 & $11,9 \%$ \\
\hline & 75-79 tahun & 7 & $10,4 \%$ \\
\hline \multirow[t]{3}{*}{2.} & Jenis Kelamin & & \\
\hline & Laki-laki & 19 & $28,4 \%$ \\
\hline & Perempuan & 48 & $71,6 \%$ \\
\hline
\end{tabular}

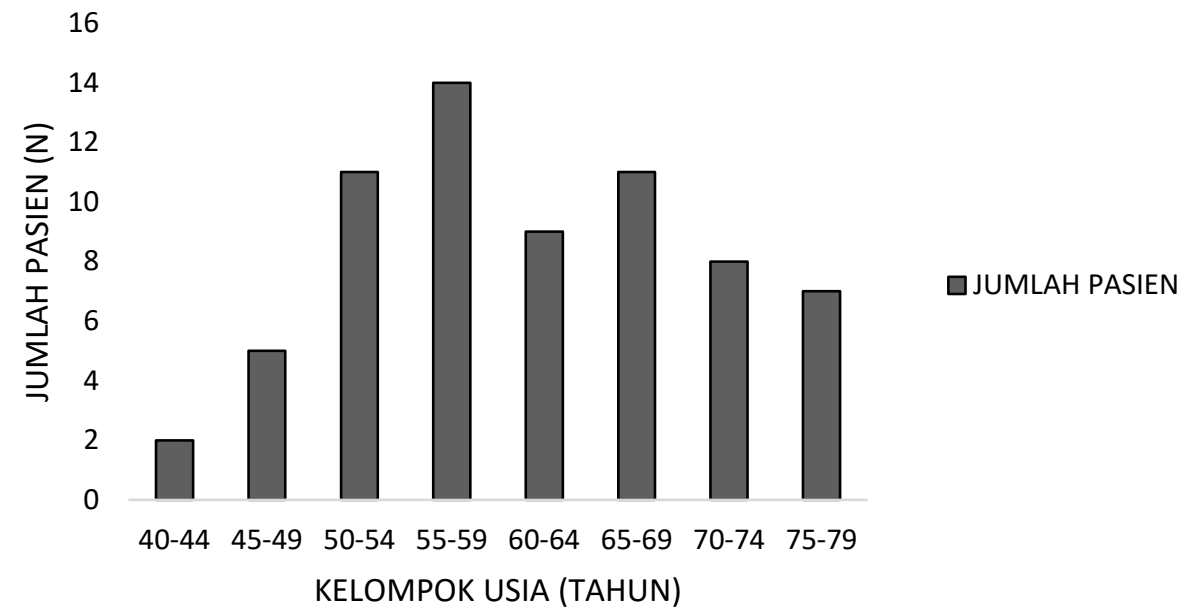

\section{Gambar 1 Jumlah Pasien Osteoartritis Sendi Lutut Primer pada Setiap Kelompok Usia}

Tabel 2 menunjukkan derajat osteoartritis sendi lutut primer berdasarkan sistem klasifikasi Kellgren-Lawrence yang diderita oleh pasien dari setiap kelompok usia. Secara keseluruhan, derajat osteoartritis sendi lutut primer yang paling sering ditemukan pada pasien adalah derajat 3 dengan jumlah pasien sebanyak 25 (37,3\%). Tabel 2 menunjukkan bahwa osteoartritis derajat berat atau 4 paling sering ditemukan pada kelompok usia 55-59 tahun sebanyak 3 pasien (33,3\%) dan kelompok usia 60-64 tahun sebanyak 3 pasien (33,3\%). 


\section{Research Article}

Tabel 2 Derajat Osteoartritis Sendi Lutut Primer pada Setiap Kelompok Usia

\begin{tabular}{|c|c|c|c|c|c|c|c|c|c|c|}
\hline \multirow[t]{2}{*}{ Usia } & \multicolumn{2}{|c|}{$\begin{array}{c}\text { Derajat } 0 \\
(\mathrm{n}=2)\end{array}$} & \multicolumn{2}{|c|}{$\begin{array}{c}\text { Derajat } 1 \\
(n=7)\end{array}$} & \multicolumn{2}{|c|}{$\begin{array}{c}\text { Derajat } 2 \\
(\mathrm{n}=24)\end{array}$} & \multicolumn{2}{|c|}{$\begin{array}{c}\text { Derajat } 3 \\
(n=25)\end{array}$} & \multicolumn{2}{|c|}{$\begin{array}{c}\text { Derajat } 4 \\
(n=9)\end{array}$} \\
\hline & $\mathrm{n}$ & $\%$ & $\mathrm{n}$ & $\%$ & $\mathrm{n}$ & $\%$ & $\mathrm{n}$ & $\%$ & $\mathrm{n}$ & $\%$ \\
\hline 40-44 tahun & - & - & - & - & - & - & 1 & $4 \%$ & 1 & $11,1 \%$ \\
\hline 45-49 tahun & - & - & 1 & $14,3 \%$ & 1 & $4,2 \%$ & 3 & $12 \%$ & - & - \\
\hline 50-54 tahun & 1 & $50 \%$ & 2 & $28,6 \%$ & 4 & $16,7 \%$ & 3 & $12 \%$ & 1 & $11,1 \%$ \\
\hline 55-59 tahun & 1 & $50 \%$ & - & - & 4 & $16,7 \%$ & 6 & $24 \%$ & 3 & $33,3 \%$ \\
\hline 60-64 tahun & - & - & - & - & 3 & $12,5 \%$ & 3 & $12 \%$ & 3 & $33,3 \%$ \\
\hline 65-69 tahun & - & - & - & - & 5 & $20,8 \%$ & 6 & $24 \%$ & - & - \\
\hline $70-74$ tahun & - & - & 2 & $28,6 \%$ & 3 & $12,5 \%$ & 3 & $12 \%$ & - & - \\
\hline $75-79$ tahun & - & - & 2 & $28,6 \%$ & 4 & $16,7 \%$ & - & - & 1 & $11,1 \%$ \\
\hline
\end{tabular}

Persentase yang tertulis di tabel 2 menunjukkan persentase jumlah penderita osteoartritis sendi lutut pada suatu kelompok usia yang dibandingkan dengan jumlah total penderita osteoartritis sendi lutut pada derajat osteoartritis sendi lutut tersebut. Perhitungan persentase dilakukan secara vertikal.

Hasil penilaian dari 67 subjek yang diteliti, dilakukan uji korelasi Spearman untuk mengetahui korelasi antara usia dan derajat osteoartritis sendi lutut primer pasien. Dari uji korelasi didapati koefisien korelasi sebesar $-0,15(\mathrm{p}=0,224)$ sehingga tidak terdapat korelasi antara usia dan derajat osteoartritis sendi lutut primer berdasarkan sistem klasifikasi Kellgren-Lawrence.

\section{Diskusi}

Osteoartritis sendi lutut adalah penyakit kronis dari sendi sinovial yang ditandai dengan pelemahan kartilago artikular yang diikuti dengan pertumbuhan osteofit, pembentukan kista dan sklerosis pada tulang subkondral, sinovitis ringan, dan fibrosis kapsul sendi. ${ }^{15}$ Seiring meningkatnya usia, terjadi pelemahan otot yang berfungsi untuk memperkuat sendi dan penurunan kemampuan sintesis matriks kartilago oleh kondrosit sehingga kartilago artikular menjadi semakin tipis. ${ }^{1}$ Kondrosit yang tua mensekresikan matriks metaloproteinase yang mengakibatkan terjadinya degradasi matriks kartilago. Terjadi juga penurunan sekresi growth factor yang menurunkan sintesis matriks dan perbaikan matriks kartilago. Hal ini mengakibatkan ketidakseimbangan antara proses katabolisme dan anabolisme pada kartilago sendi sehingga terjadi degradasi kartilago artikular yang menyebabkan osteoartritis. ${ }^{16}$ 


\section{Research Article}

Usia sudah diketahui sebagai salah satu faktor yang paling berpengaruh terhadap kejadian osteoartritis, akan tetapi penelitian ini mendapatkan koefisien korelasi sebesar $-0,15$ ( $\mathrm{p}=0,224)$ sehingga tidak terdapat korelasi antara usia dan derajat osteoartritis sendi lutut primer berdasarkan sistem klasifikasi Kellgren-Lawrence. Hasil dari penelitian ini sesuai dengan hasil penelitian yang dilakukan oleh Rahmadiyanti dkk yang menyatakan bahwa tidak terdapat hubungan yang bermakna antara usia dan derajat osteoartritis sendi lutut $(\mathrm{p}=0,115) .{ }^{17} \mathrm{Hal}$ ini menandakan bahwa terdapat faktor lain yang lebih memengaruhi derajat osteoartritis sendi lutut primer dari usia.

Penelitian ini mendapati bahwa kelompok usia yang paling sering menderita ostoartritis sendi lutut primer adalah kelompok usia 50-59 tahun dengan jumlah 25 pasien (37,3\%) dan diikuti oleh kelompok usia 60-69 tahun dengan jumlah 20 pasien $(29,8 \%)$. Hasil dari penelitian ini berbeda dengan hasil penelitian yang dilakukan oleh Ahmad dkk di RSUD Dr. Soetomo Surabaya pada bulan September-Oktober tahun 2016 yang mendapatkan bahwa kelompok usia 60-69 tahun (43\%) paling sering menderita osteoartritis sendi lutut dan diikuti oleh kelompok usia 50-59 tahun (29\%) pada peringkat kedua. ${ }^{18}$ Alasan perbedaan hasil antara kedua penelitian ini belum diketahui penyebabnya dan dibutuhkan penelitian lebih lanjut untuk menjawab hal ini. Penelitian yang dilakukan oleh Grace dkk di RSUP Sanglah Bali pada bulan Januari - Juni tahun 2018 menyatakan bahwa kelompok usia 60-69 tahun $(41,7 \%)$ paling sering menderita osteoartritis dan diikuti oleh kelompok usia 50-59 tahun (26,7\%) pada peringkat kedua. ${ }^{19}$

Penelitian ini juga mendapati bahwa pasien osteoartritis sendi lutut primer di RSUP Dr. Hasan Sadikin Bandung pada periode 1 Januari 2019-1 Februari 2020 lebih banyak berjenis kelamin perempuan $(71,6 \%)$ daripada laki-laki $(28,4 \%)$. Hasil ini sesuai dengan penelitian yang dilakukan oleh Grace dkk yang mendapatkan bahwa di RSUP Sanglah Bali pada bulan Januari Juni tahun 2018, pasien osteoartritis sendi lutut lebih banyak berjenis kelamin perempuan $(73,3 \%)$ daripada laki-laki (26,7\%) dan hasil dari penelitian yang dilakukan oleh Asrul yang mendapatkan bahwa di Instalasi Rawat Jalan RSUP Dr. Sardjito Yogyakarta pada bulan Februari-Mei tahun 2013, pasien osteoartritis sendi lutut lebih banyak berjenis kelamin perempuan $(61,1 \%)$ daripada laki-laki $(38,6 \%)^{19,20}$

Berdasarkan hasil penelitian ini, osteoartritis sendi lutut di atas derajat 3 paling sering ditemukan pada kelompok usia 50-59 tahun $(38,2 \%)$. Hasil yang didapat dari penelitian ini berbeda dengan hasil penelitian yang dilakukan oleh Muraki dkk di Jepang. Muraki dkk menemukan bahwa osteoartritis sendi lutut di atas derajat 3 paling sering ditemukan pada 


\section{Research Article}

kelompok usia di atas 80 tahun. ${ }^{21}$ Perbedaan ini mungkin terjadi karena perbedaan aspek sosiodemografi dan bidang pekerjaan masing-masing negara.

Berdasarkan sensus penduduk Jepang, masyarakat Jepang paling banyak bekerja di sektor kerajinan dan menjadi buruh pabrik. Di Jepang, pekerjaan peringkat ke 2 hingga ke 5 merupakan jenis pekerjaan sektor jasa. Sektor pertanian tidak termasuk dalam 5 besar sektor pekerjaan di Jepang. ${ }^{22}$ Berdasarkan data dari Dinas Pertanian Kota Bandung, tenaga kerja sektor pertanian sebesar 20,66\% dari masyarakat Bandung, menempati peringkat ke 3 terbesar di Bandung. ${ }^{23}$ Masyarakat kota Bandung yang bekerja di sektor pertanian memiliki pekerjaan dengan beban fisik berat, sering menggunakan sendi secara repetitif seperti menekuk lutut, berdiri selama lebih dari dua jam per hari. Pekerjaan dengan beban berat merupakan faktor risiko terjadinya



Keterbatasan dalam penelitian ini adalah penelitian ini hanya menganalisis korelasi antara variabel usia dan derajat osteoartritis sendi lutut primer. Variabel lain yang juga dapat memengaruhi derajat osteoartritis sendi primer lutut seperti indeks masa tubuh, lama menderita osteoartritis, kebiasaan olah raga, pekerjaan, penyakit metabolik, dan variabel lainnya tidak diteliti dalam penelitian ini. Variabel yang mungkin memengaruhi akan lebih baik jika turut dianalisis, dan perlu dilakukan juga pengambilan data dari poli penyakit dalam dan ortopedi agar hasil penelitian dapat lebih mewakili populasi pasien osteoartritis sendi lutut primer di RSUP Dr. Hasan Sadikin Bandung.

\section{Simpulan}

Tidak terdapat korelasi antara usia dan derajat osteoartritis sendi lutut primer berdasarkan sistem klasifikasi Kellgren-Lawrence di Departemen Radiologi RSUP Dr. Hasan Sadikin Bandung pada tahun 2019-2020.

\section{Daftar Pustaka}

1. Harrison T, Kasper D. Harrison's principles of internal medicine. New York: McGraw-Hill Medical Publ. Division; 2015. p.2226-30.

2. Cotran R, Kumar V, Robbins S. Pathologic basis of disease. Philadelphia, PA: Saunders Elsevier; 2015. p.1208-9.

3. Arden N, Nevitt MC. Osteoarthritis: epidemiology. Best Pract Res Clin Rheumatol. 2006;20(1):3-25.

4. Glyn-Jones S, Palmer AJR, Agricola R, Price AJ, Vincent TL, Weinans H, et al. Osteoarthritis. Lancet. 2015;386(9991):376-87.

5. Indonesian Rheumatology Association. Diagnosis dan Penatalaksanaan Osteoartritis. Rekomendasi IRA untuk Diagnosis dan Penatalaksanaan Osteoartritis. 2014. p.2

6. Heidari B. Knee osteoarthritis prevalence, risk factors, pathogenesis and features: Part I. Casp J Intern Med. 2011;2(2):205-12. 


\section{Research Article}

7. Musumeci G, Aiello FC, Szychlinska MA, Di Rosa M, Castrogiovanni P, Mobasheri A. Osteoarthritis in the XXIst century: Risk factors and behaviours that influence disease onset and progression. Int J Mol Sci. 2015;16(3):6093112 .

8. Loeser RF. The Role of Aging in the Development of Osteoarthritis. Trans Am Clin Climatol Assoc. 2017;128:4454.

9. Sen R, Hurley JA. Osteoarthritis. [Updated 2020 Mar 30]. In: StatPearls [Internet]. Treasure Island (FL): StatPearls Publishing; 2020 Jan-. Available from: https:/www.ncbi.nlm.nih.gov/books/NBK482326/

10. Sinusas K. Osteoarthritis: Diagnosis and treatment. Am Fam Physician. 2012;85(1):49-56.

11. Wright RW, Ross JR, Haas AK, Huston LJ, Garofoli EA, Harris D, et al. Osteoarthritis classification scales: Interobserver reliability and arthroscopic correlation. J Bone Jt Surg - Am Vol. 2014;96(14):1145-51.

12. Kohn MD, Sassoon AA, Fernando ND. Classifications in Brief: Kellgren-Lawrence Classification of Osteoarthritis. Clin Orthop Relat Res. 2016;474(8):1886-93.

13. National Institute for Health and Clinical Exellence (NICE). Commisioning Guide: Painful Osteoarthritis of the Knee. R Coll Surg Engl. 2017;(2.1):1-18.

14. Kellgren JH, Lawrence JS. Radiological Assessment of Osteo-Arthrosis I: 1956;(4):494-502.

15. Solomon L, Warwick D, Nayagam S. Apley's system of orthopaedics and fractures. 9th ed. Hodder Arnold; 2010.

16. Anderson AS, Loeser RF. Why is OA an age-related disease. Best Pr Res Clin Rheumatol. 2010;24(1):1-18.

17. Rahmadiyanti N, Tresnasari C, Rahmawatyalie I. Hubungan Antara Usia dan Jenis Kelamin dengan Derajat Keparahan Osteoarthritis Lutut di RS Al-Islam Bandung Periode 1 Januari 2013-2014. 2015;764-72.

18. Ahmad IW, Rahmawati LD, Wardhana TH. Demographic Profile, Clinical and Analysis of Osteoarthritis Patients in Surabaya. Biomol Heal Sci J. 2018;1(1):34.

19. Claudia G, Saturti TIA, Kurniari PK. Karakteristik Penderita Osteoartritis Lutut Di Rsup Sanglah Periode JanuariJuni 2018. E-Jurnal Med Udayana;2020;9(7):23-8.

20. Ismail A. Gambaran Karakteristik Pasien Osteoartritis di Instalasi Rawat Jalan RSUP dr. Sardjito Yogyakarta. 2017;5(4):303-6.

21. Muraki S, Akune T, Oka H, Ishimoto Y, Nagata K, Yoshida M, et al. Incidence and risk factors for radiographic $\mathrm{k}$ nee osteoarthritis and knee pain in Japanese men and women: a longitudinal population-based cohort study. Arthri tis Rheum. 2012 May;64(5):1447-56.

22. Statistics Bureau M. Statistics Bureau Home Page/Summary of Third Basic Complete Tabulation Results [Interne t]. Stat.go.jp. 2021 [cited 23 February 2021]. Available from: https://www.stat.go.jp/english/data/kokusei/1995/15 133.html

23. Bandung D. [Internet]. Distan.bandungkab.go.id. 2021 [cited 23 February 2021]. Available from: https://distan.ba ndungkab.go.id/selayang-pandang

24. Yucesoy B, Charles LE, Baker B, Burchfiel CM, Branch MB, Effects H, et al. HHS Public Access. 2015;50(2):26 $1-73$. 